\title{
PENINGKATAN PRODUKTIVITAS PETERNAK SAPI DI DAERAH TRANSMIGRASI LUBUK AUR SITIUNG I KABUPATEN DHARMASRAYA
}

\author{
Ediset $^{1)}$, Jaswandi ${ }^{2)}$, Edwin Heriyanto ${ }^{3)}$ dan Basril Basyar ${ }^{4)}$ \\ ${ }^{1)}$ Fakultas Peternakan, Universitas Andalas, email : edisetjami80@gmail.com \\ ${ }^{2)}$ Fakultas Peternakan, Universitas Andalas, email : Jaswandi_J@yahoo.co.id \\ ${ }^{3)}$ Fakultas Peternakan, Universitas Andalas, email : edwin.heriyanto@yahoo.co.id \\ ${ }^{4)}$ Fakultas Peternakan, Universitas Andalas, email : basrilbasyar@yahoo.co.id
}

\begin{abstract}
ABSTRAK
Kegiatan penyuluhan secara tidak langsung merupakan bagian dari upaya untuk mendukung pembangunan peternakan, melalui transfer ilmu dan teknologi diharapkan terjadi adopsi inovasi sehingga terjadi perubahan perilaku pada peternak, baik itu perubahan pengetahuan (koqnitif), perubahan sikap (afektif) maupun perubahan keterampilan (pisikomotor). Ilmu dan teknologi yang ditawarkan dalam kegiatan penyuluhan ini adalah penguatan kelembagaan, motivasi usaha, reproduksi ternak, pemanfaatan limbah pertanian kakao sebagai pakan ternak dan pemanfaatan limbah kotoran ternak. Metoda yang digunakan dalam kegiatan pengabdian ini adalah metode Penyuluhan melalui pendekatan ceramah/pidato, kunjungan rumah dan usahatani serta pendekatan demonstrasi, setelah dilakukan penyuluhan dilakukan pembinaan dan evaluasi terhadap kegiatan yang sudah dilakukan. Kegiatan ini diharapkan dapat meningkatkan motivasi peternak, meningkatkan pengetahuan (koqnitif) dan keterampilan peternak (psykomotorik) dalam menerapkan suatu inovasi serta peternak mau dan mampu menerapkan inovasi (afektif) yang ditawarkan oleh oleh narasumber, sehingga pada gilirannya usaha peternakan sapi yang digeluti oleh peternak mampu meningkatkan pendapatan sehingga mampu memperbaiki perekonomian rumah tangga peternak. Pelaksanaan kegiatan ini menghasilakn beberapa perubahan pada peternak sasaran, seperti muncul keinginan untuk membuat kelompok baru dan mendaftarkan kelompok tersebut pada instansi terkait untuk mendapatkan legalitas keberadaan kelompok. Peternak sasaran kegiatan mengalami peningkatan pengetahuan terutama tentang tanda tanda birahi pada ternak sapi, pemanfaatan limbah pertanian kakao sebagai pakan ternak serta pengetahuan tentang pemanfaatan limbah kotoran ternak untuk dijadikan suatu produk yang bernilai ekonomi.
\end{abstract}

Kata Kunci : Penyuluhan, Inovasi, Perubahan Perilaku, Peternak sapi

\section{ENHANCING PRODUCTIVITY OF CATCHERS IN THE AREA OF TRANSMIGRATION OF LUBUK AUR SITIUNG I DISTRICT DHARMASRAYA}

\author{
Ediset $^{1)}$, Jaswandi ${ }^{2)}$, Edwin Heriyanto ${ }^{3)}$ and Basril Basyar ${ }^{4)}$ \\ ${ }^{1)}$ Faculty of Animal Husbandry, Andalas University, email : edisetjami80@gmail.com \\ ${ }^{2)}$ Faculty of Animal Husbandry, Andalas University, email : Jaswandi_J@yahoo.co.id \\ ${ }^{3}$ Faculty of Animal Husbandry, Andalas University, email : edwin.heriyanto@yahoo.co.id \\ ${ }^{4)}$ Faculty of Animal Husbandry, Andalas University, email : basrilbasyar@yahoo.co.id
}

\begin{abstract}
Indirect counseling activities are part of efforts to support livestock development, through the transfer of science and technology is expected to occur the adoption of innovation so that there is a change of behavior in the breeders, whether it changes knowledge (koqnitif), attitude changes (affective) and skills changes (psykomotorik). The science and technology offered in this extension activity is institutional strengthening, business motivation, livestock reproduction, utilization of cocoa farm waste as animal feed and utilization of cattle dung waste. The method used in this devotional activity is the method of counseling through the approach of lectures / speeches, home visits and farming and demonstration approaches, after the counseling done coaching and evaluation of activities that have been done. This activity is expected to increase the motivation of farmers, improve the knowledge (koqnitif) and skills of
\end{abstract}


farmers (psykomotorik) in applying an innovation and breeders willing and able to apply innovation (affective) offered by the speakers, so in turn cattle breeding business that is cultivated by farmers are able Increase the income so as to improve the household economy of farmers. The implementation of these activities resulted in some changes to the target farmers, such as the desire to create new groups and register the group with relevant agencies to obtain the legality of group existence. Target farmers experience increased knowledge, especially about the signs of lust in cattle, the use of agricultural waste cocoa as animal feed and knowledge of the use of cattle manure waste to be a product of economic value.

\section{Keywords: Counseling, Innovation, Behavior Change, Cattle ranchers}

\section{PENDAHULUAN}

\section{Analisa Situasi}

Peternakan sapi merupakan salah satu jenis usaha peternakan yang paling banyak dilakukan oleh masyarakat terutama masyarakat yang ada di daerah transmigrasi Kabupaten Dharmasraya, dimana di daerah transmigrasi ini hampir semua rumah tangga memelihara ternak sapi secara intensif, baik itu jenis sapi simental, sapi limausin, sapi Peranakan Ongole (PO), maupun sapi pesisir dan sapi bali.

Usaha peternakan sapi di daerah ini sudah dilakukan dari sejak lama dan merupakan usaha keluarga yang bersifat turun temurun di kalangan masyarakat, usaha peternakan sapi dimulai sejalan dengan program transmigrasi yang dilakukan oleh pemerintah pusat pada tahun 1979, dimana pada waktu itu pemerintah pusat menjadikan Kabupaten Dharmasraya sebagai sala satu daerah tujuan transmigrasi. Peserta transmigrasi pada waktu itu disamping diberikan lahan untuk perumahan dan pertanian juga diberikan ternak sapi melalui program Bantuan Presiden (Banpres) untuk mendukung perekonomian rumah tangga sehingga budaya beternak sapi sampai saat ini selalu terjaga dan tetap lestari.

Kabupaten Dharmasraya merupakan daerah yang terdiri berbagai suku karena daerah ini merupakan sala satu daerah tujuan Transmigrasi di Provinsi Sumatera Barat. Dinamika kehidupan masyarakatnya pada umumnya memiliki pekerjaan sebagai petani, baik itu sebagai petani tanaman pangan, perkebunan maupun peternakan. Masyarakat di daerah transmigrasi disamping mengolah lahan pertanian sebagai usaha pokok juga melakukan usaha pemeliharaan ternak sapi disekitar areal perumahan mereka

Jorong Lubuk Aur, Nagari Gunung Medan merupakan sala satu daerah transmigrasi di Sitiung I yang sebagaian besar masyarakatnya memelihara ternak sapi dengan skala rumah tangga dengan sistem pemeliharaan yang intensif. Intensifitas sistem pemeliharaan ternak sapi disebab karena usaha ini merupakan suatu usaha tradisi keluarga yang sudah turun temurun saja, dan disamping itu peternak menganggap usaha ini cukup membantu ekonomi rumah tangga karena peternak bisa menjadikan hasil penjualan dari ternak sapi sebagai tabungan, yang biasanya dipergunakan untuk menyekolahkan anak, untuk biaya resepsi pernikahan anggota keluarga serta untuk biaya berobat.

Orientasi usaha peternakan sapi di daerah sini terlihat hanya sebagai saving sehingga hal ini menggambarkan usaha peternakan sapi bukanlah suatu usaha utama yang dapat dijadikan sebagai mata pencarian pokok bagi masyarakat, hal ini tidak terlepas dari masih kurangnya peternak di 
daerah sini menerapkan inovasi baru yang terkait dengan usaha peternakan yang mereka lakukan.

Peternak sapi di daerah transmigrasi Lubuk Aur belum semuanya tergabung dalam kelompok peternak, belum semua peternak juga yang mengadopsi inovasi bioteknologi reproduksi seperti Inseminasi Buatan (IB) dan Transfer Embrio (TE), tidak semua peternak yang tahu tentang reproduksi ternak, belum banyak juga yang memanfaatkan limbah pertanian sebagai pakan ternak serta belum tahunya peternak memanfaatkan limbah kotoran ternak. Kondisi ini seharusnya mendapat perhatian dari pemangku kepentingan peternakan, seperti Dinas Peternakan, Badan Penyuluhan Pertanian dan Peternakan setempat serta akademisi peternakan yang berasal dari Perguruan Tinggi (PT), sehingga usaha peternakan tersebut dapat menjadi usaha pokok keluarga dan mampu membuka lapangan pekerjaan baru bagi masyarakat yang ada di daerah pedesaaan. [1] menyatakan bahwa Kabupaten Dharmasraya memiliki potensi untuk pengembangan ternak sapi potong dilihat dari : 1) Aspek sumberdaya Alam (SDA) wilayah seperti ketersediaan lahan, ketersediaan pakan dan kondisi alam. 2) Aspek sosial budaya seperti pemeliharaan ternak, pendidikan peternak dan kebiasaan dalam memelihara ternak. 3) Aspek Kelembagaan seperti lembaga keuangan, administrasi pemerintah, informasi dan teknologi.

Potensi wilayah diatas tidak linear dengan pertambahan populasi ternaknya, dimana secara statistik jumlah populasi ternak sapi potong di daerah ini cendrung mengalami penurunan dari tahun sebelumnya. Data Dinas Perternakan dan Perikanan Kabupaten Dharmasraya (2014) menunjukan bahwa tahun 2012, jumlah populasi ternak sapi adalah 31.449 ekor dengan klasifikasi 7.920 ekor sapi jantan dan 23.529 ekor sapi betina, pada tahun 2013 jumlah populasi mengalami penurunan sebanyak 4.690 ekor dimana jumlah populasi ternak pada tahun 2013 sebanyak 26.759 ekor, dengan jumlah 5.808 ekor sapi jantan dan 20.951 ekor sapi betina.

\section{Permasalahan Peternak Mitra}

1. Kurangnya motivasi peternak untuk mengembangkan usaha peternakan sapi karena sampai ini hanya dalam skala kecil sehingga peluang dan potensi yang besar dalam pengembangan peternakan sapi belum dapat sepenuhnya dinikmati oleh para peternak.

2. Peternak masih banyak yang belum tergabung dalam kelompok peternak, sehingga kesulitan mengakses informasi maupun memperoleh bantuan dari pihak lain.

3. Peternak belum banyak mendapatkan penyuluhan tentang nutrisi ternak, reproduksi maupun introduksi inovasi, baik tentang teknologi pakan maupun teknologi bioteknologi reproduksi.

4. Peternak belum banyak mempunyai pengetahuan tentang pemanfaatan limbah kotoran ternak

\section{METODE PELAKSANAAN KEGIATAN}

\section{Penyuluhan}

Metode pelaksanaan untuk masing-masing solusi yang ditawarkan adalah metode penyuluhan dengan berbagai pendekatan, seperti yang diuraikan dibawah ini:

\section{a. Ceramah}

Pendekatan ceramah ini dilakukan untuk merubah perilaku peternak mitra pada aspek 
pengetahuan (koqnitif), dimana dengan untuk membantu peternak, tetapi memiliki menyampaikan materi materi yang relevan dengan kebutuhan peternak sehingga terjadi perubahan pengetahuan pada peternak. Pendekatan ini sama juga dengan pendekatan pidato yang bertujuan untuk transfer ilmu melalui pemaparan materi dari sumber pada sasaran yang dilengkapi dengan sesi diskusi/tanya jawab untuk menambah pemahaman peternak terkait dengan materi yang disampaikan. Pada pelaksanaannya anggota kelompok mitra diminta berperan aktif dan diberi kesempatan untuk dapat menyampaikan gagasan - gagasan yang ingin mereka kemukakan. [2] menambahkan bahwa pendekatan penyuluhan ceramah biasanya diikuti diskusi dengan mengajukan pertanyaan untuk menjelaskan hal hal yang penting untuk memusatkan perhatian massa pada suatu masalah.

Pendekatan penyuluhan ceramah ini di pergunakan untuk menyampaikan materi yang berkaitan dengan peningkatan motivasi dan jiwa kewirausahaan dari peternak, penguatan kelembagaan kelompok, Pengetahuan teknologi pakan, Pengetahuan tentang tanda tanda birahi, Inseminasi Buatan (IB) dan Transfer Embrio (TE), gambaran tentang pemanfaatan kotoran menjadi sesuatu yang bernilai ekonomi seperti pupuk organik.

b. Kunjungan Rumah dan Usaha Tani

Pendekatan ini dilakukan untuk mengakomodasi peternak sapi peserta kegiatan yang tidak hadir pada saat penyampaian materi, sehingga dilakukan kunjungan rumah dan usaha tani sesuai dengan ketersedia sumber daya tim pengabdian. [2] mengatakan bahwa metode kunjungan rumah dan usaha tani sangat baik

kelemahan dari aspek tenaga dan waktu.

\section{c. Demonstrasi}

[2] mengatakan bahwa ada dua macam demonstrasi, yaitu demonstrasi cara dan demonstrasi hasil. Kedua macam demonstrasi ini secara umum digunakan secara terpisah dengan materi yang agak berbeda, tetapi untuk hal-hal tertentu dapat juga dikombinasikan. Pendekatan demonstrasi dilakukan untuk beberapa kegiatan, diantara nya penentuan tanda-tanda birahi, kebuntingan, seleksi bibit, pejantan dan induk unggul, serta pemanfaatan kulit kakao sebagai pakan ternak.

\section{Pembinaan}

Setelah kegiatan penyuluhan selesai dilaksanakan, peternak akan dibina/dibimbing secara berkelanjutan mengenai permasalahan pakan, reproduksi ternak, introduksi inovasi dan pemanfaatan limbah kotoran ternak sehingga peternak diharapkan mampu menangani permasalahanyang terkait dengan pakan, reproduksi ternak, mampu mengadopsi inovasi baru yang sudah diperkenalkan dan dapat memanfaatkan limbah kotoran ternak yang pada gilirannya usaha peternakan yang dilakukan mengalami peningkatan produktivitas.

\section{Evaluasi}

Pada akhir kegiatan akan dilakukan evaluasi terhadap pengetahuan peternak sapi di daerah transmigrasi Lubuk Aur dengan melihat perubahan pengetahuan yang terjadi, baik itu perubahan pengetahuan tentang pakan ternak, reproduksi ternak, pengetahuan tentang inovasi pada teknologi pakan dan bioteknologi reproduksi maupun perubahan yang terjadi pada pengetahuan peternak tentang pemanfaatan limbah kotoran ternak. 


\section{HASIL DAN PEMBAHASAN}

\section{Motivasi Semangat Kewirausahaan}

Kegiatan ini dilakukan dengan metode penyuluhan ceramah, melalui bantuan kepala Jorong Lubuk Aur para peternak dikumpulkan di sala satu rumah peternak (12 orang) untuk mendapatkan materi dari nara sumber yang disesuai dengan rencana awal. Awal pertemuan narasumber memaparkan potensi usaha ternak sapi termasuk peluang keberhasilan dimasa yang akan datang. Pemaparan narasumber seperti diatas menimbulkan respon yang positif dari peternak perserta kegiatan pengabdian, hal ini terlihat dari banyaknya muncul pertanyaan dari peserta dan bahkan ada peserta yang meminta penjelasan kepada narasumber tentang berapa pendapatan yang diperoleh perhari dengan memelihara satu ekor ternak sapi. Proses penyuluhan yang seperti ini menggambarkan bahwa pelaksanaan kegiatan pengabdian di daerah ini terutama yang berkaitan dengan motivasi usaha berjalan sesuai dengan harapan narasumber karena dengan diskusi yang mendalam tersebut diharapkan terjadi peningkatan motivasi di kelompok sasaran. [2] mengatakan bahwa keberhasilan proses belajar dalam penyuluhan bukan ditentukan oleh jumlah materi yang disampaikan tetapi ditentukan oleh kedalaman diskusi yang terjadi antara penyuluh/narasumber dengan sasaran.

Dialog antara peternak dengan narasumber terjadi secara mendalam pada sesi ini, hal tersebut memberikan gambaran bahwa pada materi motivasi semangat kewirausahaan kegiatan penyuluhan yang dilakukan dapat merubah aspek koqnitif peternak sasaran tentang orientasi usaha yang dilakukan oleh seorang peternak, sehingga hal ini akan berdampak pada skala usaha atau jumlah populasi ternak sapi yang dipelihara. Kedalaman diskusi antara narasumber dengan sasaran tidak terlepas dari kompetensi narasumber, dimana menurut [3], kualifikasi seorang fasilitator/penyuluh (narasumber) ditentukan oleh faktor kemampuan berkomunikasi, sikap, pengetahuan tentang pesan dan kemampuan menyesuaikan diri dengan kondisi sosial budaya sasaran.

\section{Penguatan Kelembagaan}

Materi terkait dengan penguatan kelembagaan adalah legalitas kelompok, fungsi kelompok, tugas anggota dan partisipasi anggota dalam kegiatan kelompok. Kondisi lapangan pada saat kegiatan, peternak masih banyak yang belum tergabung dalam kelompok atau sebagian besar peternak sapi di daerah Jorong Lubuk Aur Nagari Gunung Medan masih melakukan usaha peternakan secara sendiri sendiri.

Waktu pelaksanaan kegiatan terjadi diskusi dan dialog yang menarik antara beberapa peternak sasaran dengan narasumber dari tim pengabdian, peternak sapi di jorong Lubuk Aur sangat senang dengan kehadiran tim pengabdian karena selama ini mereka tidak pernah dikunjungi oleh orang orang yang punya pengetahuan di bidang peternakan terutama para akademisi yang berasal dari Perguruan Tinggi.

Hasil pelaksanaan dari kegiatan penyuluhan dengan topik penguatan kelembagaan peternak ini adalah timbulnya inisiatif dari beberapa orang peternak untuk membuat kelompok kelompok peternakan baru, dimana pada waktu itu sudah mendaptar 10 orang peternak untuk membuat kelompok peternak baru. Peternak lain yang sudah tergabung dalam suatu kelompok juga 
sepakat untuk melegalkan kelompok mereka dengan cara mengurus persyaratan yang diperlukan untuk mendaftarkan kelompok mereka ke dinas terkait, dengan bukti pada waktu itu para anggota kelompok sudah mengumpulkan potocopy Kartu Tanda Pengenal (KTP) mereka ke pengurus kelompok dan setelah itu pengurus kelompok berencana akan mengurus surat persetujuan Wali Nagari Gunung Medan sebagai syarat untuk terdaftar di Dinas Peternakan dan Perikanan Kabupaten Dharmasraya. Setelah mendapatkan pengetahuan tentang pentingnya berada dalam suatu kelompok, peternak sadar bahwa hakekatnya dengan berkelompok akan mudah mengakses segala jenis akomodasi yang akan diberikan oleh pemerintah, baik itu berupa bantuan maupun berupa pinjaman.

Perubahan yang terjadi pada peternak sapi yang ada di Jorong Lubuk Aur di atas menunjukan bahwa pelaksanaan kegiatan penyuluhan tentang topik kelembagaan telah berhasil sesuai dengan harapan tim pengabdian, karena sala satu indikasi keberhasilan pelaksanaan kegiatan penyuluhan tersebut adalah ditandai dengan terjadinya perubahan perilaku. [2] menjelaskan bahwa perubahan perilaku pada sasaran penyuluhan dapat terjadi pada aspek koqnitif (pengetahuan), Aspek apektif (sikap) dan aspek psykomotor (keterampilan).

\section{Reproduksi Ternak}

Kurangnya pengetahuan masyarakat tentang cara mendeteksi birahi pda ternak. Dari informasi yang kami dapat, keluhan masyarakat adalah mereka sering kecolongan bila ternak tersebut birahi sehingga pada saat di IB ternak tidak berhasil bunting. Untuk itu kami melakukan pengenalan bagaimana cara mendeteksi birahi pada ternak. Demonstrasi ini bertujuan agar peternak mengerti bila ternaknya sedang mengalami birahi dan peternak bisa melakukan IB tepat pada waktunya.

Demonstrasi ini dilaksanakan pada tanggal 28 Juni 2016, dengan cara kunjungan ke rumah rumah warga lubuk aur yang memiliki ternak. Demonstrasi dengan cara kunjungan ini sangat bermanfaat bagi masyarakat nagari lubuk aur karna selama ini masyarakat di jorong ini tidak mengetahui sama sekali tentang cara mendeteksi birahi pada ternak khususnya sapi yang mereka pelihara sehingga jarak kebuntingannya sangatsangat jauh, dengan demonstrasi ini sekarang masyarakat sudah mengatahui cara mendetekasi birahi sehingga diharapkan jarak beranak ternak sapi ini bisa rapat dan bisa meningkatkan pendapatan peternak.

Saran untuk masyarakat agar selalu memperhatikan periode birahi sapinya agar tidak kehilangan kesempatan peluang beranak ternak tersebut dan juga masyarakat selalu memperhatikan sanitasi kandang supaya ternak lauh dari penyakit. Saran untuk pemerintah nagari/daerah agar menyediakan penyuluh dan mantri / dokter hewan yang melakukan IB di daerah tersebut.

\section{Pemanfaatan Kulit Kakao untuk Pakan Ternak}

Demonstrasi ini diadakan sebab pengetahuan masyarakat tentang penggunaan kulit kakao sebagai pakan ternak masih minim. Dari informasi yang didapat sekitar jorong lubuk aur, keluhan masyarakat adalah mereka tidak mengerti cara penggunaan pakan tersebut sehingga mereka hanya memberikan secara mentah. Sebab itulah kami memberikan inovasi 
semacam pencampuran atau dijadikan sebagai ransum dengan bahan dasar kulit kakao.

Tujuannya untuk menumbuhkan minat masyarakat dalam pengelolaan pakan ternak khususnya kulit kakao dan meningkatkan produksi ternak terutama pejantan muda dalam mengkonsumsi kulit kakao karena berguna untuk pertumbuhan ternak tersebut. Demonstrasi ini di lakukan pada tanggal 23 Juni 2016 di Lingkungan peternak sekitar jorong lubuk aur. Kegiatan ini di tujukan kepada kelompok ternak dan masyarakat sekitar jorong lubuk aur.

Demonstrasi ini sangat berguna untuk masyarakat, karena disini kita menjelaskan mulai dari cara fermentasi kulit kakao sampai pengolahan sederhana tentang kulit kakao. Banyak warga yang tidak tau cara pengolahan ini lebih menguntungkan untuk ternak karena bisa meningkatkan bobot badan dan produksi susu pada ternak sapi. Dari demonstrasi ini masyarakat bisa tahu bagaimana pemberian kulit kakao yang benar untuk ternak dan secara tidak langsung masyarakat belajar membuat ransum sederhana.

\section{Pemanfaatan Limbah Kotoran Ternak}

Kegiatan ini ditujukan untuk menstimulan pikiran peternak akar mau dan mampu memanfaatkan limbah kotoran ternak sapi, baik itu limah padat yang berupa feses, limbah cair yang berasal dari urine maupun gas yang dihasilkan oleh kotoran tersebut. Pada kesempatan penyampaian materi ini diberikan gambaran pada peternak tentang bagaimana limbah kotoran ternak tersebut dapat dijadikan suatu produk yang mempunyai nilai ekonomis.

Sasaran kegiatan selama ini hanya menumpuk kotoran ternak mereka disamping kandang ternak sapi mereka masing masing, sehingga hal ini membuat kandang mereka sangat kotor disaat musim hujan dan disamping itu keberadaan kotoran yang menumpuk tersebut menimbulkan aroma yang tidak sedap bagi anggota keluarga peternak karena hampir semua peternak sapi di Jorong Lubuk Aur mendirikan kandang ternak yang berdekatan dengan rumah, dimana hanya berjarak sekitar 5 meter dan bahkan ada kandang yang bergandengan dengan diding rumah mereka.

Peternak sapi sasaran peserta kegiatan di introduksikan beberapa jenis hasil pengolahan limbah kotoran ternak menjadi suatu produk yang punya nilai jual, seperti pemanfaatan limbah kotoran ternak sebagai sumber energi yang dikenal dengan istilah Biogas yang sekaligus bisa menghasilakan pupuk ,baik itu pupuk padat (feses) maupun pupuk cair (urine). [4] mengatakan bahwa kotoran ternak sapi dapat di olah menjadi energi alternatif biogas yang ramah lingkungan karena mampu memanfaatkan alam tanpa merusaknya sehingga siklus ekologi tetap terjaga dan manfaat lain mengelola kotoran sapi menjadi energi alternatif biogas adalah dihasilkannya pupuk organik untuk tanaman. 


\section{Dokumentasi Kegiatan}
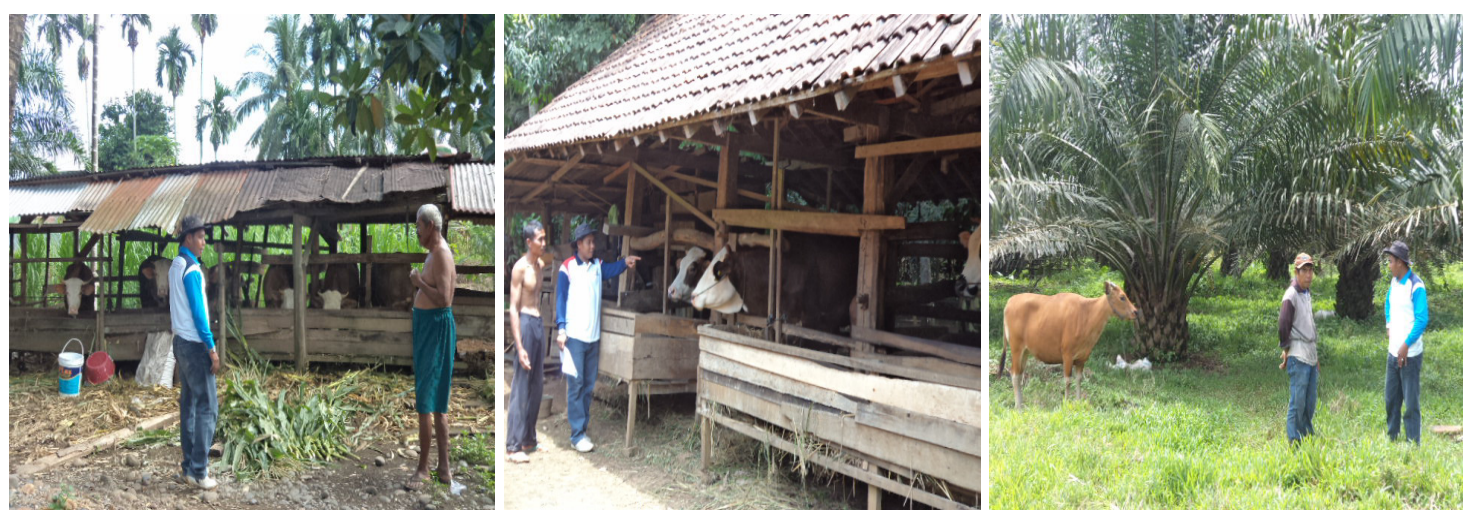

Gambar 1. Metode Kujungan Rumah dan Usaha Tani
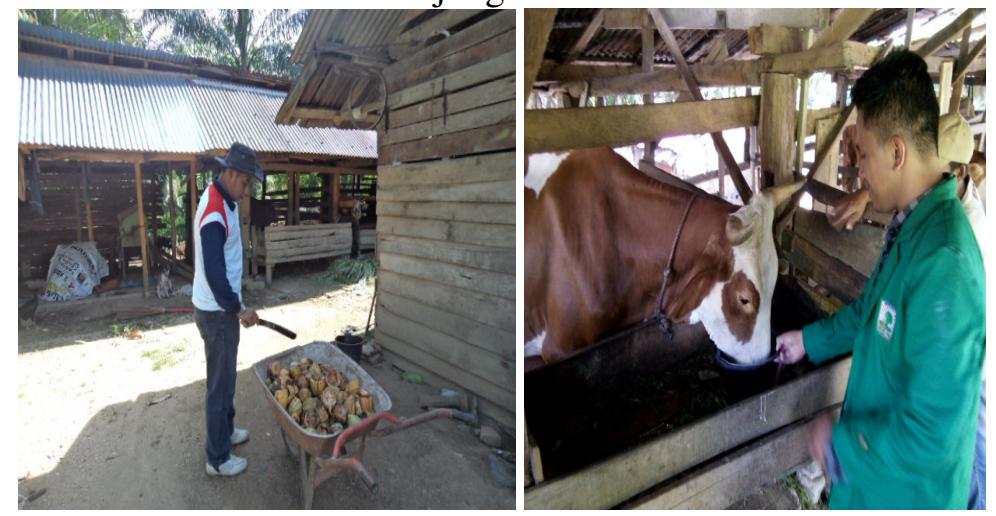

Gambar 2. Introduksi Pakan Ternak sapi dari Limbah Kakao (metode Demonstrasi)
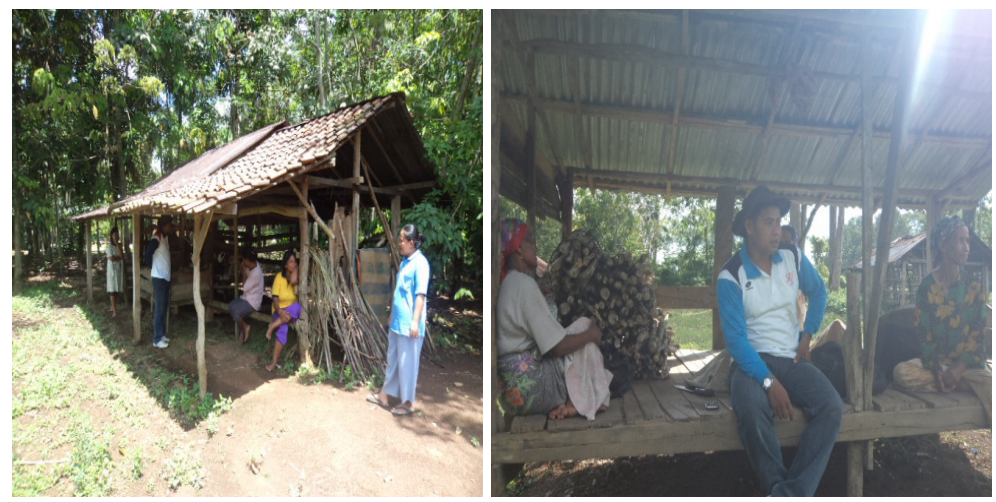

Gambar 3. Metode ceramah dalam Penyampaian Materi

\section{KESIMPULAN}

1. Peternak sapi di Jorong Lubuk Aur mengalami perubahan perilaku terutama pada aspek pengetahuan, baik pada aspek reproduksi, aspek pakan maupun pada aspek pemanfaatan limbah kotoran sebagai sesuatu yang punya nilai ekonomis.
2. Perubahan sikap peternak terjadi pada penguatan kelembagaan, dimana akan mencul kelompok peternak baru dan terdaftarnya kelompok kelompok peternak tersebut di Dinas terkait.

3. Keterampilan peternak mengalami peningkatan terutama dalam menentukan tanda tanda birahi pada ternak dan 
pengolahan limbah kakao sebagai pakan alternatif untuk ternak sapi.

\section{SARAN}

1. Perlu di introduksikan inovasi baru jenis lain pada peternak sapi di Jorong Lubuk Aur Nagari Gunung Medan Kabupaten Dharmasraya.

2. Lembaga terkait seperti Dinas Peternakan dan Badan Penyuluhan daerah setempa seharusnya berkomitmen untuk mendukung usaha peternakan sapi yang sudah dilakukan oleh peternak sehingga usaha yang mereka lakukan mampu memberdayakan ekonomi peternak.

3. Tanggung jawab Perguruan Tinggi sebagai sumber ilmu dan teknologi harus diterjemahkan dalam kegiatan pembinaan terhadap masyarakat, peternak sapi di daerah transmigrasi khususnya.

\section{REFERENSI}

1. Ediset dan Jaswandi. 2014. Karakteristik Peternak dan Aspek teknis Usaha Peternakan Sapi Potong di Daerah Transmigrasi Kabupaten Dharmasraya. Jurnal Agrotropical Volume 4 no 1. STIPER Sawahlunto Sijunjung.

2. Hawkins, H.S. dan A.W. Van Den Ban. 1999. Penyuluhan Pertanian, Diterjemahkan oleh Agnes Dwina Herdiasti. Kanisius, Jakarta.

3. Anwar, S; Madariza, F. dan Anas, A. 2009. Ilmu Penyuluhan Pertanian. Universitas Andalas, Padang.

4. Mardikanto.2010. Komunikasi Pembangunaan. Acuan Bagi Akademisi, Praktisi dan Peminat Komunikasi Pembangunaan. UNS Press, Surakarta.

5. Ramaiyulis. 2012. Materi Pelatihan. Apresiasi Penyuluh Bidang Peternakan. Dinas Peternakan Provinsi Sumatera Barat. Padang. 